\title{
Quality of life, health conditions and life style of civil police officers
}

\author{
Qualidade de vida, condições de saúde e estilo de vida de policiais civis \\ Calidad de vida, condiciones para la salud y estilo de vida para policías civiles
}

\author{
Francis Ghignatti da Costa ${ }^{a}$ \\ Lizandra Santos Vieira ${ }^{b}$ \\ Mateus Gomes Cócaro ${ }^{b}$ \\ Karina de Oliveira Azzolin ${ }^{b}$ \\ Daiane Dal Pai ${ }^{\mathrm{b}}$ \\ Juliana Petri Tavares ${ }^{b}$
}

How to cite this article:

Costa FG, Vieira LS, Cócaro MG, Azzolin KO, Dal Pai D, Tavares JP. Quality of life, health conditions and life style of civil police officers. Rev Gaúcha Enferm. 2020;41:e20190124. doi: https://doi. org/10.1590/1983-1447.2020.20190124 autonomous Researcher. Porto Alegre, Rio Grande do Sul, Brasil.

b Universidade Federal do Rio Grande do Sul (UFRGS) Escola de Enfermagem. Porto Alegre, Rio Grande do Sul, Brazil

\section{ABSTRACT}

Objectives: Evaluate the relation between quality of life, health conditions and life style of Civil Police Officers in Porto Alegre/RS. Method: Transversal study with 237 police officers that answered a questionnaire containing socio-occupational information, life style, health conditions and the instrument World Health Quality of Life (WHOQOL-bref). The data was collected in 2018 and submitted to statistical analysis.

Results: Broad domain of quality of life showed higher rates in non-hypertensive subjects $(p=0,002)$, without cardiovascular alterations ( $p=0,001)$, non-smokers $(p=0,003)$, no alcohol ingestion $(p=0,036)$, regular physical activity $(p<0,001)$, healthy eating $(p<0,001)$, no use of medication $(p=0,028)$, able to have time to rest $(p=0,049)$. Correlated with sleeping, weight, abdominal and hip circumference $(p<0.01)$.

Conclusion: Chronic diseases, use of medication and unhealthy lifestyle are related to worsening health-related quality of life. Keywords: Occupational health. Nursing. Police. Quality of life. Life style.

\section{RESUMO}

Objetivo: Avaliar a relação entre qualidade de vida, condições de saúde e estilo de vida em policiais civis de Porto Alegre/RS.

Método: Estudo transversal com 237 policiais que responderam um questionário com informações sociolaborais, estilo de vida, condições de saúde e o instrumento World Health Quality of Life-bref. Os dados foram coletados em 2018 e submetidos à análise estatística.

Resultados: 0 Domínio Geral da qualidade de vida apresentou maiores médias para não hipertensos $(p=0,002)$, sem alterações cardiovasculares $(p=0,001)$, não tabagistas $(p=0,003)$, não consumidores de bebida alcoólica $(p=0,036)$, exercem atividade física $(p<0,001)$, mantém alimentação saudável $(p<0,001)$, não usam medicamentos $(p=0,028)$, com tempo para descanso $(p=0,049)$. Correlacionou-se com sono, peso, circunferência abdominal e de quadril $(p<0,01)$.

Conclusão: Doenças crônicas, uso de medicamentos e estilo de vida não saudável relacionaram-se com piora na qualidade de vida. Palavras-chave: Saúde do trabalhador. Enfermagem. Polícia. Qualidade de vida. Estilo de vida.

\section{RESUMEN}

Objetivo: Evaluar la relación entre calidad de vida, condiciones de salud y estilo de vida entre policías civiles de Porto Alegre/RS. Método: Estudio transversal con 237 policías que respondieron un cuestionario con datos inherentes a información sociolaboral, estilo de vida, condiciones de salud y el instrumento World Health Quality of Life-bref. La recolección de datos se realizó en 2018 y los mismos fueron sometidos a análisis estadísticos.

Resultados: El dominio general de la calidad de vida presentó mejores resultados en los siguientes casos: no hipertensos $(p=0,002)$, sin alteraciones cardiovasculares $(p=0,001)$, no tabaquistas $(p=0,003)$, no consumidores de bebidas alcohólicas $(p=0,036)$, realización de actividades físicas $(p<0,001)$, consumo de alimentos saludables $(p<0,001)$, no utilización de medicamentos $(p=0,028)$, disposición de tiempo de descanso $(p=0,049)$. Se relacionó con los siguientes factores: sueño, peso, circunferencia abdominal y de cadera $(p<0,01)$.

Conclusión: Las enfermedades crónicas, el uso de medicamentos y el estilo de vida no saludable se relacionan con el empeoramiento de la calidad de vida.

Palabras clave: Salud laboral. Enfermería. Policía. Calidad de vida. Estilo de vida. 


\section{口INTRODUCTION}

Police work worldwide is characterized by exposure to stress and risk of death ${ }^{(1-2)}$. Thus, police activity requires professionals to act in confrontation with the irregular or criminal conduct of society, risking their own lives in favor of defending the life of the other ${ }^{(3)}$.

The role of police officers is not limited to daily service, it also implies a constant state of alert ${ }^{(3)}$, representing a work-centered lifestyle(4). Thus, this context can be a risk factor for the health of these workers, so that the quality of life, health conditions and lifestyle can be negatively affected.

Health conditions are defined as circumstances in the health of the population that present themselves in a more or less persistent way and that demand social responses, coming from health professionals, health care systems and people using the service. Among these conditions, we can mention the occurrence of chronic non-communicable diseases ${ }^{(5)}$, such as Systemic Arterial Hypertension (SAH) and Diabetes Mellitus (DM). SAH is considered an illness inherent in the police profession, since the tension experienced during working hours, associated with risk factors, influences the imbalance of cardiovascular function ${ }^{(6)}$. Furthermore, professionals with DM have a favorable circumstance for the development of $\mathrm{SAH}$, mainly due to the high body mass index that affects this professional category ${ }^{(7)}$.

Physical exhaustion, consisting of factors such as heavy workload, few hours of sleep/rest, psychological stress and vulnerability to risks, can cause illnesses related to the nature of the services provided by the police officer ${ }^{(7)}$. In addition, the events experienced during the work shift influence the perception of the quality of life of these professionals ${ }^{(8)}$ and increases the risk for cardiovascular disorders ${ }^{(9)}$.

Exposure to threats and risks in the field of work directly influences the quality of life of workers, which is defined as the perception of insertion in life, in the context of culture and value systems in relation to their objectives, their expectations, standards and concerns $s^{(8,10)}$, when considering the possibility of a physical or psychological illness related to daily work ${ }^{(2)}$. Therefore, in order to exercise their functions, the police must be prepared and strengthened in terms of physical and mental aspects, with a view to meeting the new and growing demands of society, involving public security issues and presenting great challenges to the fight against violence ${ }^{(11)}$

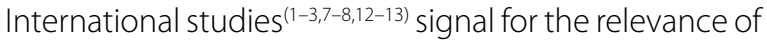
investigations about changes in the health of the police, in view of the importance of this group for the society. Research is mainly about stress and resilience ${ }^{(1)}$, stress and quality of life ${ }^{(2-3)}$, Diabetes Mellitus ${ }^{(7)}$, cardiovascular changes ${ }^{(8,12)}$ and metabolic syndrome and quality of life ${ }^{(13)}$. However, few national studies ${ }^{(6,8,11)}$ have been addressing these issues, especially with regard to health, lifestyle and quality of life, reflecting the existence of a gap to be answered.

The realization of studies covering this professional category makes it possible to clarify how the situational circumstances of the work affect the health and quality of life of the police. In this perspective, the following issues are questioned: is there a relationship between quality of life, health conditions and lifestyle among civil police officers? Therefore, this study aims to assess the relationship between quality of life, health conditions and lifestyle among civil police officers in Porto Alegre/RS.

\section{METHOD}

Cross-sectional quantitative study, developed with the 12 departments that make up the Civil Police of Porto Alegre - RS. The departments aim to preserve the public security of the population, developing activities of protection and defense, using information technology for investigations, and specializing in vulnerable groups. The study population consisted of 1600 police officers. The sample size calculation was performed using the software $G *$ Power Version 3.1.2 (2009), considering levels of statistical power of $95 \%$, for a significance level of 5\%, obtaining a sample of 237 civil police officers, proportionally distributed among the departments. The parameters used for the sample calculation were based on other studies that used the same predictor variables and the studied outcome ${ }^{(2)}$.

For sampling, two criteria were used, one specific for Police Stations, in which sampling by clusters was adopted due to the high number of police stations, all belonging to the same department. The other criterion was directed to the Police Departments, whose selection was random, stratified with systematic random drawing, based on the list of active workers during the study period. The sample included active subjects, aged between 18 and 65 years old, who were assigned to the Civil Police of Porto Alegre/ RS. The exclusion criteria of the sample were established as police officers who had worked for less than one year in the corporation, police officers who were away from work and function in the Porto Alegre police or on leave for any reason during the data collection period.

Data collection was carried out from August 2017 to July 2018, in the workplace, by three nursing students and a master's student, who were previously trained. The questionnaire included socio-occupational information, lifestyle 
and health conditions, which were constructed based on the scientific literature consulted by the researchers. Socio-labor characteristics were assessed by the variables: Gender, age, marital status, education, time in the job, police activity, position. Health conditions were addressed through questions regarding the presence of cardiovascular changes, SAH, $D M$, the use of medications and the perception of changes in physical health after joining the civil police, in addition to the collection of anthropometric data, such as weight, circumference of abdomen and hips.

Weight was measured using a digital scale, previously calibrated and certified by the National Institute of Metrology, Quality and Technology (INMETRO). The abdominal circumference was measured horizontally at the height of the umbilical scar, at the mean distance between the last floating rib and the iliac crest, without applying pressure; and the circumference of the hip was measured with the measuring tape positioned in the area of greatest gluteal protuberance, close to the region of the trochanter of the femur.

As for lifestyle, the variables sleep hours, smoking, alcohol consumption, food, performance and frequency of physical activity, time available for leisure and rest were included.

Quality of life, the outcome variable, was assessed using the World Health Quality of Life (WHOQOL-bref) developed by the Quality of Life Group of the World Health Organization and validated in Brazi ${ }^{(14)}$. The WHOQOL-bref has 26 questions grouped into five domains: Physical (PHD), Psychological (PSD), Social Relations (SRD), Environment (ED) and General (GD), being characterized as: Physical (pain, energy, sleep, mobility, activities of daily living, dependence on medication/ treatments, ability to work); Psychological (positive $\bigvee$ negative feelings, thoughts, self-esteem, body image, spirituality); Social relationships (personal relationships, social support and sexual activity); Environment (physical security, home environment, financial resources, health and social care, opportunities to acquire information and skills, recreation/ leisure, physical environment and transportation); General (overall quality of life and perceptions of general health).

In addition to this categorization, a descriptive analysis of demographic and socio-occupational data was carried out to characterize the research participants. The Statistical Package for Social Sciences (SPSS) software, version 20.0 was used for the quantitative data. The Shapiro-Wilk normality test was used to verify the distribution of variables, in addition to the values of asymmetry and kurtosis. Student's t-test was used for association between variables with symmetrical distribution; and, for the asymmetric ones, Mann-Whitney. For the association between categorical variables, the chi-square test, or Fisher's exact test, was used when any cell has an expected frequency lower than five. Pearson (for symmetric variables) and Spearman (for asymmetric variables) correlations were performed. Data with two-tailed "p" less than 0.05 or with a $95 \%$ confidence interval were considered as statistically significant differences.

The research was approved by the Research Ethics Committee CAAE 65391717.1.0000.5347 and complied with ethical prerogatives involving human beings, according to Law 466 of 2012 of the National Health Council (Conselho Nacional de Saúde - CNS). The study participants signed the Informed Consent Form, confirming voluntary participation, the protection of anonymity and the confidentiality of information.

\section{RESULTS}

Sociodemographic and work data are described in table 1. Regarding the police officers'lifestyle, cigarette smoking was not a frequently adopted practice, $8 \%(n=19)$ reported daily use. However, in relation to the consumption of alcoholic beverages, more than half $(54.4 \%, n=129)$ reported consuming them. Regarding the time for rest and leisure, the highest percentage of police officers $(59.5 \%, n=141)$ reported having enough time to carry out these practices. The workers had a median of 7 (6-8) hours of sleep. As for the regular practice of physical activity, $67.9 \%(n=161)$ performed it at least once a week and $73.8 \%(n=175)$ reported adopting a healthy diet.

Regarding health conditions, the prevalence of chronic non-communicable diseases, such as Systemic Arterial Hypertension and Diabetes mellitus, based on self-reported medical diagnosis, was $16 \%(n=38)$ and $2.5 \%(n=6)$, respectively. Regarding drug use, $65.8 \%$ of the police reported not using it to treat general health conditions. As for the search for health treatments, a percentage of $20 \%$ was observed for those who are interested in routine evaluations. Regarding anthropometric measurements, weight registered a median of 72 (61-85) kilograms, abdominal circumferences, 86 (7596), and hip circumference, 103 (98-108).

Regarding the physical changes perceived after joining the civil police, $41.35 \%(n=98)$ of the professionals showed changes in their health status, so that $23.5 \%(n=23)$ of these had SAH ( $p=0.009$ ) and $14.3 \%$, cardiovascular changes ( $p=$ $0.001)$. Among the professionals who manifested cardiovascular changes $(7.2 \%, n=17), 52.9 \%$ had SAH $(p<0.001)$. The variable unhealthy eating, the use of continuous medications and physical changes showed a statistically significant difference when associated with SAH $(p<0.05)$, and not significant with DM ( $p>0.05)$. Among police officers who 
reported eating unhealthily $(n=16), 25.8 \%$ had $\mathrm{SAH}$ ( $\mathrm{p}=$ 0.015). As for the use of continuous medications, $37 \%$ of police officers had SAH ( $p<0.001)$ and 7.4\% DM ( $p=0.001)$. The other variables in question did not show a significant association with SAH and DM ( $p>0.05)$.
Table 2 represents the distribution of the variables health conditions in general and life habits of civil police workers with WHOQOL quality of life domains.

Table 3 shows the distribution of life habits of civil police workers with the WHOQOL quality of life domains.

Table 1 - Characterization of Civil Police officers according to sociodemographic data. Porto Alegre, 2018

\section{Sociodemographic variables}

Gender

Male

Female

\section{n=237}

123(51.9)

114(48.1)

$$
\text { Age* }^{*}
$$

Marital status

Single or No companion

Married or with Companion

\begin{tabular}{lc}
\hline $\begin{array}{l}\text { Number of Children* } \\
\text { Has Higher Education } \\
\text { No } \\
\text { Yes }\end{array}$ & $1(0-1)$ \\
\hline $\begin{array}{l}\text { Schooling* } \\
\text { Belief/Religiosity } \\
\text { No }\end{array}$ & $222(94.1)$ \\
Yes & $17(16-19)$ \\
\hline $\begin{array}{l}\text { Working Period* } \\
\text { Time in this Job }\end{array}$ & $66(27.8)$ \\
\hline Daily Workday* & $171(72.2)$ \\
\hline $\begin{array}{l}\text { Sector } \\
\text { Administrative activity. }\end{array}$ & $7(3-16)$ \\
Registry Office \\
Investigation \\
$\begin{array}{l}\text { On Duty } \\
\text { Others }\end{array}$ & $6(3-14)$ \\
\hline $\begin{array}{l}\text { Position } \\
\text { Scribe } \\
\text { Inspector } \\
\text { Delegate }\end{array}$ & $8(8-8)$ \\
\hline
\end{tabular}

$81(34.2)$

156(65.8)

$39.5(34.25-48.00)$

$1(0-1)$

14(5.9)

Source: Research data, 2018

*Median 
Table 2 - Distribution of quality of life domains WHOQOL-bref according to variable health conditions in general of civil police workers, Porto Alegre/RS, 2018

\begin{tabular}{|c|c|c|c|c|c|c|}
\hline & & PHD & PD & SRD & ED & GD \\
\hline \multirow[t]{3}{*}{ Systemic Arterial Hypertension* } & No & $12.81 \pm 1.45$ & $14.24 \pm 1.60$ & $15.48 \pm 2.52$ & $13.96 \pm 2.09$ & $15.02 \pm 2.54$ \\
\hline & Yes & $13.26 \pm 1.61$ & $13.85 \pm 1.66$ & $15.50 \pm 2.46$ & $13.92 \pm 2.32$ & $13.57 \pm 2.79$ \\
\hline & & $p=0.08$ & $p=0.182$ & $p=0.956$ & $p=0.913$ & $p=0.002$ \\
\hline \multirow[t]{3}{*}{ Cardiovascular Alteration* } & No & $12.87 \pm 1.49$ & $14.23 \pm 1.60$ & $15.51 \pm 2.52$ & $14.00 \pm 2.06$ & $14.94 \pm 2.53$ \\
\hline & Yes & $13.04 \pm 1.47$ & $13.49 \pm 1.60$ & $15.13 \pm 2.40$ & $13.29 \pm 2.82$ & $12.82 \pm 3.16$ \\
\hline & & $p=0.648$ & $p=0.067$ & $p=0.551$ & $p=0.185$ & $p=0.001$ \\
\hline \multirow[t]{3}{*}{ Diabetes mellitus* } & No & $12.87 \pm 1.49$ & $14.20 \pm 1.60$ & $15.49 \pm 2.53$ & $13.96 \pm 2.10$ & $14.83 \pm 2.57$ \\
\hline & Yes & $13.23 \pm 1.16$ & $13.33 \pm 1.78$ & $15.33 \pm 1.39$ & $13.50 \pm 3.20$ & $13.00 \pm 4.51$ \\
\hline & & $p=0.555$ & $p=0.194$ & $p=0.879$ & $p=0.597$ & $p=0.092$ \\
\hline \multirow[t]{3}{*}{ Medication* } & No & $12.89 \pm 1.42$ & $14.27 \pm 1.59$ & $15.61 \pm 2.52$ & $14.08 \pm 1.99$ & $15.06 \pm 2.61$ \\
\hline & Yes & $12.86 \pm 1.61$ & $13.99 \pm 1.63$ & $15.24 \pm 2.48$ & $13.70 \pm 2.36$ & $14.27 \pm 2.62$ \\
\hline & & $p=0.913$ & $p=0.196$ & $p=0.279$ & $p=0.191$ & $p=0.028$ \\
\hline Weight $^{\dagger}$ & & $\begin{array}{l}r=0.085 \\
p=0.285\end{array}$ & $\begin{array}{l}r=-0.064 \\
p=0.418\end{array}$ & $\begin{array}{l}r=-0.020 \\
p=0.802\end{array}$ & $\begin{array}{l}r=-0.036 \\
p=0.647\end{array}$ & $\begin{array}{l}r=-0.194 \\
\mathbf{p}=\mathbf{0 . 0 1 4}\end{array}$ \\
\hline Abdominal Circumference ${ }^{\dagger}$ & & $\begin{array}{l}r=0.072 \\
p=0.273\end{array}$ & $\begin{array}{l}r=-0.062 \\
p=0.346\end{array}$ & $\begin{array}{l}r=-0.016 \\
p=0.803\end{array}$ & $\begin{array}{l}r=-0.128 \\
p=0.051\end{array}$ & $\begin{array}{l}r=-0.252 \\
p<\mathbf{0 . 0 0 1}\end{array}$ \\
\hline Hip circumference ${ }^{\dagger}$ & & $\begin{array}{l}r=0.088 \\
p=0.189\end{array}$ & $\begin{array}{c}r=-0.075 \\
p=0.261\end{array}$ & $\begin{array}{l}r=0.018 \\
p=0.784\end{array}$ & $\begin{array}{l}r=-0.077 \\
p=0.251\end{array}$ & $\begin{array}{l}r=-0.173 \\
\mathbf{p}=\mathbf{0 . 0 0 9}\end{array}$ \\
\hline
\end{tabular}

Source: Research data, 2018.

* Mean \pm Standard Deviation, ${ }^{\dagger}$ Correlation

Table 3 - Distribution of quality of life domains WHOQOL-bref according to variable life habits of civil police workers, Porto Alegre/RS, 2018

\begin{tabular}{lcccccc} 
& & PD & PD & SRD & ED & GD \\
Smoking & No & $12.89 \pm 1.46$ & $14.19 \pm 1.63$ & $15.54 \pm 2.50$ & $14.01 \pm 2.12$ & $14.94 \pm 2.54$ \\
& Yes & $12.69 \pm 1.76$ & $13.96 \pm 1.73$ & $14.80 \pm 2.47$ & $13.23 \pm 2.09$ & $13.05 \pm 3.08$ \\
& & $p=0.562$ & $p=0.546$ & $p=0.218$ & $p=0.126$ & $\mathbf{p}=\mathbf{0 . 0 0 3}$ \\
\hline Alcohol & No & $12.94 \pm 1.44$ & $14.19 \pm 1.67$ & $15.40 \pm 2.69$ & $14.04 \pm 2.12$ & $15.18 \pm 2.47$ \\
& Yes & $12.83 \pm 1.52$ & $14.17 \pm 1.56$ & $15.55 \pm 2.34$ & $13.87 \pm 2.14$ & $14.46 \pm 2.73$ \\
& & $p=0.576$ & $p=0.921$ & $p=0.652$ & $p=0.551$ & $\mathbf{p}=\mathbf{0 . 0 3 6}$ \\
\hline Physical activity* & No & $12.57 \pm 1.56$ & $13.87 \pm 1.72$ & $15.15 \pm 2.80$ & $13.52 \pm 2.31$ & $13.60 \pm 2.82$ \\
& Yes & $13.02 \pm 1.43$ & $14.32 \pm 1.54$ & $15.64 \pm 2.35$ & $14.15 \pm 2.01$ & $15.53 \pm 2.35$ \\
& & $\mathbf{p}=\mathbf{0 . 0 3 1}$ & $\mathbf{p}=\mathbf{0 . 0 4 7}$ & $p=0.165$ & $\mathbf{p = 0 . 0 3 3}$ & $\mathbf{p}<\mathbf{0 . 0 0 1}$ \\
\hline
\end{tabular}


Table 3 - Cont.

\begin{tabular}{|c|c|c|c|c|c|c|}
\hline & & PD & PD & SRD & ED & GD \\
\hline \multirow[t]{3}{*}{ Food* } & Unhealthy & $12.44 \pm 1.53$ & $13.68 \pm 1.89$ & $15.46 \pm 2.78$ & $13.69 \pm 2.33$ & $13.54 \pm 2.86$ \\
\hline & Healthy! & $13.03 \pm 1.44$ & $14.35 \pm 1.46$ & $15.49 \pm 2.41$ & $14.04 \pm 2.05$ & $15.23 \pm 2.41$ \\
\hline & & $p=0.007$ & $p=0.014$ & $p=0.926$ & $p=0.261$ & $p<0.001$ \\
\hline \multirow[t]{3}{*}{ Rest $^{*}$} & No & $12.16 \pm 1.38$ & $13.23 \pm 1.73$ & $13.90 \pm 1.86$ & $12.57 \pm 0.93$ & $12.85 \pm 2.26$ \\
\hline & Yes & $12.90 \pm 1.49$ & $14.20 \pm 1.60$ & $15.53 \pm 2.51$ & $13.99 \pm 2.14$ & $14.85 \pm 2.63$ \\
\hline & & $p=0.196$ & $p=0.117$ & $p=0.090$ & $p=0.081$ & $p=0.049$ \\
\hline \multirow[t]{3}{*}{ Leisure* } & No & $12.32 \pm 2.25$ & $12.47 \pm 2.39$ & $15.04 \pm 2.85$ & $12.78 \pm 3.64$ & $13.42 \pm 2.76$ \\
\hline & Yes & $12.89 \pm 1.46$ & $14.23 \pm 1.56$ & $15.50 \pm 2.50$ & $13.99 \pm 2.07$ & $14.83 \pm 2.62$ \\
\hline & & $p=0.317$ & $p=0.004$ & $p=0.638$ & $p=0.417$ & $p=0.165$ \\
\hline \multirow[t]{3}{*}{ Physical change* } & No & $13.06 \pm 1.43$ & $14.46 \pm 1.48$ & $15.82 \pm 2.36$ & $14.38 \pm 1.88$ & $15.38 \pm 2.40$ \\
\hline & Yes & $12.62 \pm 1.53$ & $13.77 \pm 1.71$ & $15.00 \pm 2.63$ & $13.34 \pm 2.32$ & $13.95 \pm 2.73$ \\
\hline & & $p=0.025$ & $p=0.001$ & $p=0.013$ & $p<0.001$ & $p<0.001$ \\
\hline \multirow[t]{2}{*}{ Sleep ${ }^{\dagger}$} & & $r=0.203$ & $r=0.072$ & $r=0.053$ & $r=0.146$ & $r=0.192$ \\
\hline & & $p=0.002$ & $p=0.271$ & $p=0.417$ & $p=0.025$ & $p=0.003$ \\
\hline \multirow[t]{2}{*}{ Rest $^{*}$} & No & $12.16 \pm 1.38$ & $13.23 \pm 1.73$ & $13.90 \pm 1.86$ & $12.57 \pm 0.93$ & $12.85 \pm 2.26$ \\
\hline & Yes & $12.90 \pm 1.49$ & $14.20 \pm 1.60$ & $15.53 \pm 2.51$ & $13.99 \pm 2.14$ & $14.85 \pm 2.63$ \\
\hline
\end{tabular}

Source: Research data, 2018.

${ }^{*}$ Mean \pm Standard Deviation, ${ }^{\dagger}$ Correlation

The police officers who exercised regular physical activity had higher means in the Physical Domain (PHD), in the Psychological Domain (PSD) and in the Environment Domain (ED); those who ate healthy showed higher means in the Physical Domain (PHD) and Psychological Domain (PSD) of the WHOQOL-bref $(p<0.05)$. The PD also showed higher means for police officers who engaged in leisure activity $(p=0.004)$. There was a correlation between the sleep variable and the PHD $(r=0.230 ; p=0.002)$ and the ED $(r=0.146 ; p=0.025)$.

The police officers who showed no change in physical health after joining the police showed higher means in all domains of the WHOQOL-bref $(p<0.05)$. The General Domain (GD) had higher means for those who did not have SAH ( $p=$ 0.002 ), had no cardiovascular changes ( $p=0.001$ ), were not smokers ( $p=0.003)$, did not consume alcoholic beverages $(p=0.036)$, exercised physical activity $(p<0.001)$, ate healthy $(p<0.001)$, did not use medication to treat unspecified health conditions ( $p=0.028)$, had time to rest ( $p=0.049)$. Still, the sleep variables $(r=0.192 ; p=0.003)$, weight $(r=-0.194$; $p=0.014)$, abdominal circumference $(r=-0.252 ; p<0.001)$ and hip circumference $(r=-0.173 ; p=0.009)$ correlated with the WHOQOL-bref.

\section{DISCUSSION}

This study made it possible to obtain relevant information about workers assigned to the Civil Police of Porto Alegre/RS. Among the findings, it was observed that SAH prevalence of SAH is $16 \%$ in the study population. The analyzes carried out identified that the adoption of healthy eating habits and physical exercise practices at least once a week are present in the daily life of police officers.

A previous study carried out with workers in the city of Rio de Janeiro, identified a prevalence of $16.1 \%$ of self-reported SAH, similar to the results of this research. In addition, the complication among police officers was associated with a high level of body mass, hypercaloric and hyperlipidic intake and stress experienced at work. Another factor considered decisive for illness is sedentary lifestyle, leading to impairment of energy, vitality and professional efficiency(6). 
In a recent study carried out in Saudi Arabia ${ }^{(12)}$, values of 33.3\% of systemic arterial hypertension were found for overweight workers and $66.5 \%$ of professionals considered obese presented the chronic comorbidity in question, and these represented $66.9 \%$ of the sample. The authors considered that this indicates the existence of a great impact of the set of situations experienced in the daily work on the physical health of the police officers. Therefore, low levels of physical activity and nutritional awareness permeate the police class work practices, which may be having a negative impact on the health and quality of life of these professionals.

Police officers from eastern provinces showed behavior prone to the development of coronary heart disease. Among the professionals identified as overweight and abdominal obesity (waist circumference greater than or equal to 85 $\mathrm{cm}$ ), $44.7 \%$ and $63.4 \%$ had changes of cardiovascular origin, respectively. These findings suggest that police officers have behavioral characteristics that contribute as risk factors for $S A H^{(7)}$ : Unhealthy eating habits, alcohol consumption and lack of physical activity. In this perspective, in two other studies, one Australian and one Canadian, significant cardiac changes $(p<0.05)$, related to systolic blood pressure, resulting from the daily work of civil police officers ${ }^{(9,15)}$.

Police officers identified with systemic arterial hypertension obtained lower means in the physical domain of quality of life. In addition, the use of alcohol, as well as the manifestation of cardiovascular changes after joining the police, is associated with lower means of global quality of life.

A study carried out in the national territory found that civil police officers with hypertension and other risk factors for cardiovascular disease, including changes in laboratory tests and abdominal obesity by assessing waist circumference, showed the adoption of a lifestyle with a negative impact on the general quality of life of these workers ${ }^{(13)}$. There is also a recent study, carried out in Ethiopia, on the consumption of alcohol and tobacco in the police community, which showed impairment in the quality of life among those who identified themselves as daily smokers (83\%) and daily alcohol consumers $(24.6 \%)^{(7)}$.

A study carried out in South China, with the objective of evaluating the health-related quality of life of police officers, found lower quality of life in this group when compared to the adult population in general, and that anxiety/depression was the most frequently reported problem. Age, alcohol consumption, physical activity, occupational damage and anxiety/depression symptoms significantly influenced the decrease in quality of life ${ }^{(16)}$.

Regarding the findings of this study, there were higher means of quality of life among police officers who reported having enough time to perform leisure and rest activities and a positive correlation between sleep and quality of life. The practice of physical activity and adherence to healthy eating habits resulted in higher means in quality of life domains. The use of medication to treat unspecified health conditions resulted in lower means.

A recent survey in Iran corroborates this perception, which identified statistical significance between quality of life and better sleep conditions, considering that the performance of practices that make rest possible reduces the prevalence of sleep disorders and poor quality of life among police officers ${ }^{(17)}$. Therefore, the hours and the quality of the policeman's sleep can be affected by the high psychic demand existing at work, as well as the excess of daily activities and the constant state of alertness: Police officers are often called on to act in people's prisons and illegal merchandise seizures during the night.

With regard to the low frequency of physical activity during the time that would be intended for leisure, associated with unhealthy eating habits, another Brazilian study highlighted that these are risk factors related to a low health-related quality of life ${ }^{(8)}$.

Regarding the use of medicines, it was evidenced in an Italian study ${ }^{(18)}$, that the use of drug therapies maintains good health and quality of life. However, another study with a similar population found that police officers with greater losses in quality of life regularly use medications ${ }^{(19)}$. Therefore, it is necessary to consider that the use of medications by the civil police in this study can be related to the control of diseases that cause physical and psychological limitations, and which can influence all areas of quality of life.

The final results of this study showed that weight was inversely correlated with the general domain and with the abdominal and hip circumferences, showed a negative correlation with the general domain of quality of life. This result can be compared with that obtained through a North American study, in which professionals with overweight and abdominal obesity, with a waist circumference value greater than or equal to $102 \mathrm{~cm}$, had a lower quality of life than professionals with weight and circumference in standards of normality ${ }^{(20)}$. In this perspective, Brazilian research obtained similar data when determining the relationship between waist $\bigvee$ weight as a risk factor associated with low health-related quality of life ${ }^{(8)}$. It became evident that the longer the police action, the higher the BMI, which may indicate that the more time police officers dedicate to their work, the less health care ${ }^{(21)}$.

In view of this, it was observed in workers with SAH the existence of risk factors for cardiovascular problems and for cardiac alterations related to daily life habits, factors that have an impact on the quality of life manifested by civil police 
officers. Thus, corroborating with authors, interventions in the workplace of police officers are necessary, including recruitment of employees, better work organization and promotion of resources in order to support the well-being of police officers ${ }^{(16)}$, as well as actions focused on the reformulation of organizational and public policies aimed at preventing occupational risks and diseases ${ }^{(22)}$.

\section{GONCLUSION}

Given the aforementioned, it is possible to conclude that variables such as the presence of $\mathrm{SAH}$, cardiovascular disorders, smoking, alcohol consumption, unhealthy eating, medication use, insufficient time for rest and leisure are correlated with lower means in the WHOQOL-bref. Likewise, there is a positive correlation for hours of sleep and an inverse correlation between weight, waist and hip circumference with the domains of quality of life, indicating a relationship between health conditions, lifestyle and quality of life of police officers.

It was found that, in the perception of the civil police, there were changes in their health status in general after entering the profession. The highest means of the WHOQOL-bref were seen in police officers who have a healthy diet, who are not smokers, who do not consume alcoholic beverages and who exercise regularly, in addition to a direct correlation between hours of sleep and the quality of life domains. Therefore, workers with a healthy lifestyle have better means in the Physical, Environment and General Domains, representing a better quality of life than the opposite group.

Given the considerations presented here, regarding a theme still little explored, it becomes noticeable that the results contribute to teaching, assistance and research in the field of health, especially in the area of occupational health. Therefore, the importance of developing nursing actions is emphasized, with an emphasis on comprehensive health care for police officers, with a view to promoting and protecting their health, with the purpose of helping them in the recovery and prevention of service time-related damage.

In this way, the health unit responsible for supporting police officers can structure themselves according to the demands and needs presented by individuals, in order to organize an efficient planning, guaranteeing security and respecting the rights of the police in the exercise of its functions, a way to consolidate work dynamics in favor of a healthier lifestyle.

Emphatically addressing the working conditions of the public security professional can contribute to the restructuring of public policies to address the identified problems and their prevention, since the theme of worker health within the scope of the work of public security agents allows observing how working conditions affect the health and quality of life of civil police officers.

The study's limitation is related to the cross-sectional design, in which all measurements are performed in a single moment without a follow-up period. In addition, the use of an instrument made with self-referred questions about the life and health habits of police officers can be a limiting aspect, considering that professionals with comorbidities could be unaware of this condition due to the low demand for health care. Therefore, the importance of new studies on the theme is emphasized, considering that the relationship between the variables presented is little observed in the current literature.

\section{Q REFERENCES}

1. Galatzer-Levy IR, Steenkamp MM, Brown AD, Qian M, Inslicht S, Henn-Haase $C$, et al. Cortisol response to an experimental stress paradigm prospectively predicts long-term distress and resilience trajectories in response to active police service. J Psychiatr Res. 2014;56:36-42. doi: https://doi.org/10.1016/j. jpsychires.2014.04.020

2. Alexopoulos EC, Palatsidi V, Tigani X, Darviri C. Exploring stress levels, job satisfaction, and quality of life in a sample of police officers in Greece. Saf Health Work. 2014;5(4):210-5. doi: https://doi.org/10.1016/j.shaw.2014.07.004

3. Lipp MEN, Costa KRSN, Nunes VO. [Stress, quality of life, and occupational stressors among police officers: frequent symptoms]. Rev Psicol Organ Trab. 2017;17(1):46-53. Portuguese. doi: https://doi.org/10.17652/rpot/2017.1. 12490

4. Habersaat SA, Geiger AM, Abdellaoui S, Wolf JM. Health in police officers: role of risk factor clusters and police divisions. Soc Sci Med. 2015;143:213-22. doi: https://doi:10.1016/j.socscimed.2015.08.043

5. Mendes EV. 0 cuidado das condições crônicas na atenção primária à saúde: 0 imperativo da consolidação da estratégia da saúde da família. Brasilia: OrganizaçãoPan-Americanada Saúde. 2012 [citado 2019mar 14].Disponívelem: http://bvsms.saude.gov.br/bvs/publicacoes/cuidado_condicoes_atencao_ primaria_saude.pdf

6. Minayo $M C$, Assis SG, Oliveira RVC. TThe impact of professional activities on the physical and mental health of the civil and military police of Rio de Janeiro (RJ, Brazil)]. Ciênc Saúde Coletiva. 2011;16(4):2199-209. Portuguese. doi: https:// doi.org/10.1590/S1413-81232011000400019

7. Tesfave T, Shikur B, Shimels T, Firdu N. Prevalence and factors associated with diabetes mellitus and impaired fasting glucose level among members of federal police commission residing in Addis Ababa, Ethiopia. BMC Endocrine Disorders. 2016;16:68. doi: https://doi.org/10.1186/s12902-016-0150-6

8. Silva FC, Hernandez SSS, Arancibia BAV, Castro TLS, Gutierres Filho PJB, Silva R. Health-related quality of life and related factors of military police officers. Health Qual Life Outcomes. 2014;12:60. doi: https://doi. org/10.1186/1477-7525-12-60

9. Elliot IL, Lal S. Blood pressure, sleep quality and fatigue in shift working police officers: effects of a twelve hour roster system on cardiovascular and sleep health. Int J Environ Res Public Health. 2016;13(2):172. doi: https://doi. org/10.3390/ijerph13020172 
10. Organización Mundial de La Salud (CH). Promoción de la salud: glosario. Ginebra: OMS; 1998 [cited 2019 Jan 10]. Disponible en: https://apps.who. int/iris/bitstream/handle/10665/67246/WHO_HPR_HEP_98.1_spa. pdf;jsessionid=CDD92CD5AA7293EF988555E1B247519F? sequence $=1$

11. Oliveira LCN, Quemelo PRV. Qualidade de vida de policiais militares. Arq Ciênc Saúde. 2014 [cited 2019 Mar 14];21(3):72-5. Available from: http://repositorioracs.famerp.br/racs_ol/vol-21-3/IDZ-642-(21-3)-jul-Set-2014.pdf

12. Alghamdi AS, Yahya MA, Alshammari GM, Osman MA. Prevalence of overweight and obesity among police officers in Riyadh City and risk factors for cardiovascular disease. Lipids Health Dis. 2017;16(1):79. doi: https://doi. org/10.1186/s12944-017-0467-9

13. Braga Filho RT, D'Oliveira Júnior A. Metabolic syndrome and military policemen's quality of life: an interdisciplinary comprehensive approach. Am J Mens Health. 2014;8(6):503-9. doi: https://doi.org/10.1177/1557988314526750

14. Fleck MPA, Louzada S, Xavier M, Chachamovich E, Vieira G, Santos L, et al. [Application of the Portuguese version of the abbreviated instrument of quality life WHOQ0L-bref]. Rev Saúde Pública. 2000;34(2):178-83. Portuguese. doi: https://doi.org/10.1590/S0034-89102000000200012

15. Gendron P, Lajoie C, Laurencelle L, Trudeau F. Cardiovascular health profile among Quebec male and female police officers. Arch Environ Occup Health. 2019:74(6):331-40. doi: https://doi.org/10.1080/19338244.2018.1472063

16. WuX, Liu Q, Li Q, Tian Z, Tan H. Health-related quality of life and its determinants among criminal police officers. Int J Environ Res Public Health. 2019;16(8):1398. doi: https://doi.org/10.3390/ijerph16081398

17. Roustaei N, Jamali H, Jamali RM, Nourshargh P, Jamali J. The association between quality of sleep and health-related quality of life in military and nonmilitary women in Tehran, Iran. Oman Med J. 2017;32(2):124-30. doi: https:// doi.org/10.5001/omj.2017.22
18. Barraco G, Pagano S, Lupoli G, Dolci A, Colagrosso B. Multitarget survey on the Finance Police personnel: assessment of the health condition. Ann Stomatol (Roma). 2014;V(4):123-7. doi: https://doi.org/10.11138/ ads\%2F2014.5.4.123

19. Wagner LC, Stankievich RAP, Pedroso F. [Mental health and quality of life of civil police officers in the metropolitan region of Porto Alegre, Rio Grande do Sul, Brazil]. Rev Bras Med Trab. 2012 [cited 2018 Dec 02];10(2):64-71. Portuguese. Available from: http://www.rbmt.org.br/details/77/pt-BR/saude-mental-equalidade-de-vida-de-policiais-civis-da-regiao-metropolitana-de-portoalegre

20. Fekedulegn D, Burchfiel CM, Hartley TA, Andrew ME, Charles LE, Zara CAT, et al. Shiftwork and sickness absence among police officers: the BCOPS study. Chronobiol Int. 2015;30(7):930-41. doi: https://doi.org/10.3109/07420528.2 013.790043

21. Vancini RL, Lira CAB, Anceschi SA, Rosa AV, Lima-Leopoldo AP, Leopoldo AS, et al. Anxiety, depression symptoms, and physical activity levels of eutrophic and excess-weight Brazilian elite police officers: a preliminary study. Psychol Res Behav Manag. 2018;11:589-95. doi: https://doi.org/10.2147/PRBM. S186128

22. Wolter C, Santa Maria A, Wörfel F, Gusy B, Lesener T, Kleiber D, et al. Job demands, job resources, and well-being in police officers: a resource-oriented approach. J Police Crim Psych. 2019;34(1):45-54. doi: https://doi.org/10.1007/ s11896-018-9265-1

\section{Acknowledgments:}

To Conselho Nacional de Desenvolvimento Científico e Tecnológico (CNPq) for the financial support. Process No. 436261/2018-9.

\section{- Corresponding author:}

Juliana Petri Tavares

E-mail:jupetritavares@gmail.com

\section{Associate editor:}

Wiliam Wegner 